\title{
A hard nut to crack: nutmeg cultivation and the application of natural history between the Maluku islands and Isle de France (1750s-1780s)
}

\author{
DORIT BRIXIUS *
}

\begin{abstract}
One of France's colonial enterprises in the eighteenth century was to acclimatize nutmeg, native to the Maluku islands, in the French colony of Isle de France (today's Mauritius). Exploring the acclimatization of nutmeg as a practice, this paper reveals the practical challenges of transferring knowledge between Indo-Pacific islands in the second half of the eighteenth century. This essay will look at the process through which knowledge was created - including ruptures and fractures - as opposed to looking at the mere circulation of knowledge. I argue that nutmeg cultivation on Isle de France was a complex process of creolizing expertise originating from the local populations of the plants' native islands with the horticultural knowledge of colonists, settlers, labourers and slaves living on Isle de France. In this respect, creolization describes a process of knowledge production rather than a form of knowledge. Once on Isle de France, nutmeg took root in climate and soil conditions which were different from those of its native South East Asian islands. It was cultivated by slaves and colonists who lacked prior experience with the cultivation of this particular spice. Experienced horticulturalists experimented with their own traditions. While they relied on old assumptions, they also came to question them. By examining cultivation as an applied practice, this paper argues that the creolization of knowledge was a critical aspect in French colonial botany.
\end{abstract}

\section{Isle de France and its creole flora}

Today, in the Jardin de pamplemousses, the botanical garden of the island that we now call Mauritius, we find a heroic bust of Pierre Poivre (1719-1786), who was the intendant of this former French colonial island between 1767 and 1772. After the Dutch abandoned it, the French took formal possession of this remote Indian Ocean island in 1721. The Compagnie française des Indes orientales (hereafter CIO) named it Isle de France and

\footnotetext{
* Institut historique allemand Paris. Email: dbrixius@dhi-paris.fr.

I am indebted to Šebestián Kroupa, Kit Heintzman, Catarina Madruga, António Carmo Gouveia and Pablo Gómez for their support and our stimulating conversations as I wrote this piece. The initial draft was quite different and shaped in a significant direction in which Christopher Parsons and Jim Endersby encouraged me. Nor should I neglect Dominik Hünniger, Emma Spary and the participants of the Academic Collecting and the Knowledge of Objects, 1700-1900 (5-10 September 2016) Göttingen Spirit Summer School, where I presented an earlier version of this article. I benefited greatly from discussions with them. Moreover, I thank Genie Yoo for providing full references and archival material of Het Amboinsch Kruid-Boek.
} 
used it as an entrepôt. ${ }^{1}$ This remote colonial island, however, was hardly lucrative and colonial administrators repeatedly considered abandoning it.

The global dimensions of the Seven Years War (1754-1763), in which France suffered a crushing defeat, shaped the development of Isle de France in the second half of the eighteenth century. ${ }^{2}$ Although France kept its Caribbean colonies, the territorial downsizing in the Atlantic that followed was significant and the financial crisis of the French monarchy provoked major shifts in colonial governance. ${ }^{3}$ The French colonial administration attempted to compensate for the Atlantic losses through tightening its grip in the Indian Ocean. ${ }^{4}$ The CIO's administration of Isle de France was replaced by an island administration directly nominated by the Ministry of the Navy and the Colonies. ${ }^{5}$ This crucial moment overlapped with colonial innovations, traditional approaches and new commercial visions including the acclimatization of nutmeg. ${ }^{6}$

The rivalry between the great European powers pushed French interest in trade towards the Pacific. This meshed with the promotion of natural-historical knowledge and resulted in increasing contact with the Indo-Pacific world. ${ }^{7}$ The transplantation of nutmeg illustrates the roles of Indo-Pacific islands for the collection, transfer and accumulation of plants and knowledge between South East Asian islands (where knowledge was acquired) and the South West Indian Ocean island (where knowledge was applied and adapted). For this purpose, I explore the production of knowledge about nutmeg cultivation as it moved between the Maluku islands and Isle de France.

Like other Indian Ocean islands, Isle de France was an enclosed space with no indigenous inhabitants or a flora suitable for commerce and food production. ${ }^{8}$ Therefore, over

1 Cf. Patrick Joseph Barnwell and Auguste Toussaint, A Short History of Mauritius, London: Longmans, Green \& Co, 1949; Auguste Toussaint, Histoire des îles mascareignes, Paris: Berger-Levrault, 1972. On Pamplemousses see Guy Rouillard and Joseph Guého, Le Jardin des pamplemousses: 1729-1979, Les Pailles (Mauritius): Henry, 1983.

2 On the global dimension of the Seven Years War see especially Daniel Albert Baugh, The Global Seven Years War, 1754-1763, Harlow and New York: Longman, 2011; Frans De Bruyn and Shaun Regan (eds.), The Culture of the Seven Years' War: Empire, Identity, and the Arts in the Eighteenth-Century Atlantic World, Toronto: University of Toronto Press, 2014; and also John Gascoigne, Encountering the Pacific in the Age of Enlightenment, Port Melbourne: Cambridge University Press, 2014.

3 Christopher Hodson, The Acadian Diaspora: An Eighteenth-Century History, Oxford: Oxford University Press, 2012, p. 79.

4 Madeleine Ly-Tio-Fane, 'Pierre Poivre et l'expansion française dans l'Indo-Pacifique', Bulletin de l'Ecole française d'extrême-orient (1967) 53, pp. 453-512.

5 On the administration's change see A. Reussner, 'L'ile de France au moment de la rétrocession au roi (1767) d'après la correspondance du gouverneur Dumas et de l'intendant Poivre', Revue d'histoire des colonies (1932) 20, pp. 217-240.

6 Pernille Røge, 'A natural order of empire: the Physiocratic vision of colonial France after the Seven Years' War', in Sophus A. Reinert and Pernille Røge (eds.), The Political Economy of Empire in the Early Modern World, Houndmills: Palgrave Macmillan, 2013, pp. 32-52, 32.

7 Londa Schiebinger and Claudia Swan (eds.), Colonial Botany: Science, Commerce, and Politics in the Early Modern World, Philadelphia: University of Pennsylvania Press, 2005; Yotam Batsaki, Sarah Burke Cahalan and Anatole Tchikine (eds.), The Botany of Empire in the Long Eighteenth Century, Washington, DC: Trustees for Harvard University, 2016.

8 On creolization and slavery in Isle de France see Megan Vaughan, Creating the Creole Island: Slavery in Eighteenth-Century Mauritius, Durham, NC: Duke University Press, 2005. On the Seychelles see Deryck Scarr, Seychelles since 1770: History of a Slave and Post-slavery Society, Trenton, NJ: Africa World Press, 1999. 
the course of the eighteenth century and, indeed, to a great extent under Poivre's tenure (1767-1772), the island's population and botanical legacy were being built up through Indo-Pacific networks. ${ }^{9}$ Via them - also through an increased dependence on the slave trade-knowledge, objects, plants and people were being transferred to the French colony. Scholars have focused on the ethnic, cultural and religious diversity of Isle de France leading to creole identities of this island. ${ }^{10}$ Yet the role of knowledge traditions as an element of creolization - that is to say, with roots in more than one culture that blended borrowings with novelties have been widely neglected.

As this paper will demonstrate, examining the history of nutmeg transplantation will help scholars understand the production of botanical knowledge in late eighteenthcentury overseas territories from the ground up and reveal that the island's creolization was a complex and rich process. Due to its heterogeneous natural, social and cultural components, the history of Isle de France connects histories of its people, environment, distinct knowledge practices and related natural materials. Therefore, Isle de France became a creole island not only in terms of its population but also regarding its natural diversity and knowledge traditions. The island's history thus serves as a laboratory where these elements native to Europe, the African mainland, Madagascar and Asia were tested. ${ }^{11}$ As I will argue in this paper, the cultural and intellectual pluralism of Isle de France led to the creolization of knowledge, in an island space. Here, I examine how the hierarchy of knowledge claims and their practical implementation during cultivation can be studied through a perspective that decentres Europe by acknowledging local knowledge practices that were created in a remote island space that was, however, significantly connected via its various networks of trade and exchange of people, objects and knowledge.

Scholars who have studied the hybridization of knowledge have nonetheless neglected the interplay between theory (local natural knowledge) and practice (the application of it). ${ }^{12}$ The meaning of hybridization and the practical challenges that came with it of appropriating plant knowledge overseas for its practical ends remain a 'black box'. Studying creolization as a rich and complex process of knowledge production as opposed to a result or a description allows us to tell much richer stories of global histories. By focusing on creolization as a process and natural history as a practice, I am able to retrieve critical instances of knowledge production, different paths of knowledge, and even moments of incoherence of nutmeg cultivation from South East Asian islands to Isle de France and the contested nature of knowledge that disappeared.

9 On Poivre's tenure and his environmentalist efforts see Richard Grove, Green Imperialism: Colonial Expansion, Tropical Island Edens and the Origins of Environmentalism, 1600-1860, Cambridge: Cambridge University Press, 1995.

10 Vaughan, op. cit. (8). Though it does not focus on Isle de France, French colonial islands, creolization and race, see Mélanie Lamotte, French Colonial Encounters in the Atlantic and Indian Oceans, c.1608-1767 (in press).

11 On the African diaspora, creolization and language see Pier Larson, Ocean of Letters: Language and Creolization in an Indian Ocean Diaspora, Cambridge: Cambridge University Press, 2009.

12 Anna Winterbottom, Hybrid Knowledge in the Early East India Company World, Houndmills: Palgrave Macmillan, 2016. 
Recent scholarship on the production of scientific knowledge in the early modern French empire suggests a well-functioning centralized system: James McClellan and François Regourd have proposed the model of a 'colonial machine', by which metropolitan actors imposed absolutist state-driven power upon science in the distant colonies. ${ }^{13}$ Against this approach, I seek to reverse this top-down perspective and bring the study of colonial science down to earth. ${ }^{14}$ While metropolitan interests did shape particular early conditions for inter-colonial networks, they had far less impact on the form and content of their specific interactions. ${ }^{15}$ One should be cautious regarding the risks of overestimating the importance of European innovations for the practice of colonial science abroad. ${ }^{16}$ Instead, knowledge was produced via practice and its local appropriation. In accordance with recent critiques, I suggest that it is particularly fruitful to explore how European interpretations of non-European plants, applied knowledge and environmental conditions impacted the practice of nutmeg cultivation and shaped its overall commercial outcome. ${ }^{17}$ When knowledge was only partly transmitted, cultivators had to fill intellectual gaps with both their own knowledge traditions and their own experience. The experience of cultivation produced both new horticultural knowledge and a recognition of the limits of existing European - in this case French - science. ${ }^{18}$

Even as indigenous knowledge about fruit-bearing and non-fruit-bearing trees arrived on Isle de France, local horticulturalists faced practical challenges when seeking to apply this natural knowledge. ${ }^{19}$ The main problem remained that not all trees bore fruits because, as we call it today, nutmeg is a dioecious plant. This characteristic feature means that it has a distinct male and female specimen. While male trees remain important for pollination, only female flowers bear fruit. Contemporaries were not necessarily

13 James E. McClellan and François Regourd, The Colonial Machine: French Science and Overseas Expansion in the Old Regime, Turnhout: Brepols, 2011.

14 Loïc Charles and Paul Cheney, 'The colonial machine dismantled: knowledge and empire in the French Atlantic', Past \& Present (2013) 219, pp. 127-163.

15 Lissa Roberts, "Le centre de toutes choses": constructing and managing centralization on the Isle de France', History of Science (2014) 52, pp. 319-342. See also Karel Davids, 'On machines, self-organization, and the global traveling of knowledge, circa 1500-1900', Isis (2015) 106, pp. 866-874.

16 Charles and Cheney, op. cit. (14).

17 Roberts, op. cit. (15); Charles and Cheney, op. cit. (14); Davids, op. cit. (15). On praxeological approaches seeking to reinterpret big narratives see Dagmar Freist (ed.), Diskurse-Körper-Artefakte: Historische Praxeologie in der Frühneuzeitforschung, Bielefeld: Transcript-Verl., 2014; Freist, 'Historische Praxeologie als Mikro-Historie', in Arndt Brendecke (ed.), Praktiken der frühen Neuzeit: AkteureHandlungen-Artefakte, Weimar, Cologne and Vienna: Böhlau, 2015, pp. 62-77. Anthropologists have long suggested examining practices and consumption in both the colonies and the metropolis; see the classic Sidney Mintz, Sweetness and Power: The Place of Sugar in Modern History, New York: Viking Penguin, 1985.

18 To name some recent important contributions, Winterbottom, op. cit. (12); 'Forum: entangled histories', American Historical Review (2007), pp. 710-799. On methodological reflections on global science see Sujit Sivasundaram, 'Sciences and the global: on methods, questions, and theory', Isis (2010) 101, pp. 146-158; and Lissa Roberts, 'Situating science in global history: local exchanges and networks of circulation', Itinerario (2009) 33, pp. 9-30.

19 On sex in plants see Lincoln Taiz and Lee Taiz, The Discovery \& Denial of Sex in Plants, Oxford: Oxford University Press, 2017. On plant traders, expertise and amateur botany in Britain and France around 1800 see Sarah Easterby-Smith, Cultivating Commerce: Cultures of Botany in Britain and France, 1760-1815, Cambridge: Cambridge University Press, 2017. 
aware that maximizing profit would have required privileging female trees. Yet, more crucial for my argument, they did not have the means to control it, as I will demonstrate in the last section of this essay. While local Indo-Pacific classification systems served the practical implementation of cultivational knowledge and reproduction more specifically on Isle de France, they did not necessarily promise success. Both European and nonEuropean theoretical knowledge faced a test against reality when contemporaries tried to put knowledge into action. It is misleading to assume that particular techniques would have travelled from the metropolis to Isle de France and vice versa. As I will illustrate through the example of grafting, such methods were developed independently in different parts of the world.

Historians of colonial knowledge production have illuminated how local plant knowledge circulated or to what extent it entered European, metropolitan knowledge. ${ }^{20}$ Here, important works have highlighted the significant contribution of local informants, gobetweens and indigenous knowledge traditions; nevertheless, these same scholars all too often rely on the migration of such knowledge back to Europe in printed texts as their end point. ${ }^{21}$ In so doing, they neglect to ask about the actual practice of knowledge in the local context from which knowledge originated. The methods and techniques that were applied in new environments and faced new sociocultural contexts required reworking of extant knowledge that merits further study. As Emma Spary has put it, histoire naturelle in France certainly must not be understood solely as theoretical debates, since for contemporaries it was 'inseparable from its social implications and practical uses', from collection and classification to cultivation. ${ }^{22}$ The application of natural inquiry involving materials for cultivation has widely been understudied. ${ }^{23}$ By the

20 Schiebinger and Swan, op. cit. (7), Batsaki, Burke Cahalan and Tchikine, op. cit. (7); Harold Cook, Matters of Exchange: Commerce, Medicine, and Science in the Dutch Golden Age, New Haven, CT: Yale University Press, 2007; Londa Schiebinger, Plants and Empire: Colonial Bioprospecting in the Atlantic World, Cambridge, MA: Harvard University Press, 2004. In the context of the Franco-Spanish mission to the Andes, Neil Safier illuminated that the indigenous knowledge and local voices of the Andes and the Amazon were radically modified, if not completely erased, when new findings entered the scientific discourse, as exemplified by Denis Diderot's Encyclopédie. Neil Safier, Measuring the New World: Enlightenment Science and South America, Chicago: The University of Chicago Press, 2008, p. 9.

21 Londa Schiebinger, Secret Cures of Slaves: People, Plants, and Medicine in the Eighteenth-Century Atlantic World, Stanford, CA: Stanford University Press, 2017; Kathleen Murphy, 'Translating the vernacular: indigenous and African knowledge in the eighteenth-century British Atlantic', Atlantic Studies (2011) 8, pp. 29-48; Jorge Cañizares-Esguerra, Nature, Empire, and Nation: Explorations of the History of Science in the Iberian World, Stanford, CA: Stanford University Press, 2006. On mediators in the history of science see Simon Schaffer, Lissa Roberts, Kapil Raj and James Delbourgo, The Brokered World: GoBetweens and Global Intelligence, 1770-1820, Sagamore Beach, MA: Science History Publications, 2009.

22 Emma C. Spary, Utopia's Garden: French Natural History from Old Regime to Revolution, Chicago: The University of Chicago Press, 2000, p. 5. See also Dániel Margócsy, "Refer to folio and number": encyclopedias, the exchange of curiosities, and practices of identification before Linnaeus', Journal of the History of Ideas (2010) 71, pp. 63-89. See also Margócsy, Commercial Visions: Science, Trade, and Visual Culture in the Dutch Golden Age, Chicago: The University of Chicago Press, 2014, pp. 29-73.

23 For an outstanding example of complex creolization and materials in colonial gardens see Alette A. Fleischer, 'Rooted in fertile soil: seventeenth-century Dutch gardens and the hybrid history of material and knowledge production', PhD thesis, University of Twente, 2010. See also Judith A. Carney, Black Rice: The African Origins of Rice Cultivation in the Americas, Cambridge, MA: Harvard University Press, 2001. 
same token, scholars who have examined the circulation of plants too often neglect the movement of related practical knowledge and people. Even though scholars have shed light on the significance of embodied knowledge of slaves, for instance, we do not know much about what happened when plant material, knowledge and planters arrived separately in a site of knowledge practice, such as colonial gardens. ${ }^{24}$ The case of Isle de France serves as a case study where no knowledge tradition was well established in the mid-eighteenth century. Hence knowledge was in constant transit because of new arrivals. ${ }^{25}$

Reflecting on knowledge creolization as a critical aspect in colonial botany, this microhistorical case of the nutmeg allows us to bring together several aspects that have been treated as separate matters in the discipline. As a creole island in the making, knowledge traditions did not necessarily correspond to a pre-existing hierarchy. ${ }^{26}$ Because there was no indigenous human population, there was also a lack of a dominant or local tradition and one must consequently rethink the notion of local informants. ${ }^{27}$ Cultivators included Europeans who migrated to the island by choice, settlers born there and slaves present through forced migration. Their agricultural knowledge varied substantially across individuals - and so did their knowledge about the specificity of the nutmeg.

To understand the complex, creolizing process of nutmeg cultivation on eighteenthcentury Isle de France, this paper follows four steps. First, I will elaborate on French colonial politics and knowledge production and place French attempts to acclimatize nutmeg in their particular economic-political contexts. Second, I will explore Maluku cultivational techniques that circulated between South East Asian islands and Isle de France. Here, knowledge could not simply be applied just as plants could not simply adapt to a new climate. Practices of cultivational knowledge had to be adapted to a new sociocultural and environmental context. To this end, I will also rethink embodied knowledge and the movement of people by elaborating on the social composition of nutmeg cultivators in Isle de France's acclimatization garden. In a third step, I will examine the complexity of the Maluku world through nutmeg nomenclature the circulation of which was disrupted and thus ignored by French actors on Isle de France.

Lastly, and closely connected to the third section, I will examine the creolization of knowledge practice alongside knowledge (non-)transmission and the practical challenges of nutmeg reproduction. Isle de France's acclimatization garden served as a site of

See also Judith A. Carney and Richard N. Rosomoff, In the Shadow of Slavery: Africa's Botanical Legacy in the Atlantic World, Berkeley: University of California Press, 2009.

24 Carney, op. cit. (23). On embodied knowledge see Pamela Smith, The Body of the Artisan: Art and Experience in the Scientific Revolution, Chicago: The University of Chicago Press, 2004.

25 See also Jim Secord, 'Knowledge in transit', Isis (2004) 95, pp. 654-672.

26 On creole knowledge traditions on Atlantic islands see Pablo F. Gómez, The Experiential Caribbean: Creating Knowledge and Healing in the Early Modern Atlantic, Chapel Hill: University of North Carolina Press, 2017. For a case of knowledge production on an island with a long-established population and traditions see Sujit Sivasundaram, Islanded: Britain, Sri Lanka, and the Bounds of an Indian Ocean Colony, Chicago: The University of Chicago Press, 2013.

27 Therefore Isle de France cannot be regarded as a 'middle ground' proposed in the North American context, for instance. Cf. Richard White, The Middle Ground: Indians, Empires, and Republics in the Great Lakes Region, 1650-1815, Cambridge: Cambridge University Press, 1991. 
experimentation conditioned by plants, people and techniques that faced new environments and had therefore to be adapted in unforeseen ways. ${ }^{28}$ I claim that applied knowledge, rooted in several European and Asian traditions, was produced through a 'learning-by-doing' method while nature itself was an important component of the process that significantly shaped the outcome. ${ }^{29}$ Skilful practice required (and requires) years and years of experience. The successful transport of nutmeg to Isle de France was only the first step in a transplantation process. Only after many years did French colonial naturalists begin to understand why it was so difficult to reproduce nutmeg. Rather than concluding that the whole project was a success or a failure, this essay explores the dynamics and reasons why it was such a slow and complex process and how historical actors sought to overcome practical challenges that led to creole knowledge practices as well as creole plants in the context of Isle de France. Thus, following arguments brought forward by STS environmental historians, I suggest that the interaction between the natural world and human agency was conditioned by the plants themselves, the island's climate and the sociocultural impact of the very people who cultivated them. ${ }^{30}$

\section{Transferring the nutmeg: politics and commercial visions}

French attempts to acclimatize nutmeg have already been studied in the canonical narratives about the French spice trade in the Indian Ocean, especially the work of Madeleine Ly-Tio-Fane. ${ }^{31}$ It was a long, complex administrative and environmental struggle. The Maluku islands to which nutmeg was indigenous were Dutch territory, where the Dutch East India Company, the Vereenigde Oost-Indische Compagnie

28 Anna Winterbottom, op. cit. (12), makes a similar argument for the case of St Helena, which was, like Isle de France, a creole island.

29 Kenneth Arrow, 'The economic implications of learning by doing', Review of Economic Studies (1962) 29, pp. 155-173. Cf. Maxine Berg, 'The genesis of "useful knowledge”, History of Science (2007) 45, pp. 123$133,127$.

30 Etienne Stockland, 'Policing the oeconomy of nature: the oiseau martin as an instrument of oeconomic management in the eighteenth-century French maritime world', History and Technology (2014) 30, pp. 1-25; Grove, op. cit. (9); Lissa Roberts, 'Practicing oeconomy during the second half of the long eighteenth century: an introduction', History and Technology (2014) 30, pp. 1-16; M. Reuss and S.H. Cutliffe (eds.), The Illusory Boundary: Environment and Technology in History, Charlottesville: University of Virginia Press, 2010; Ashley Carse, 'Nature as infrastructure: making and managing the Panama Canal watershed', Social Studies of Science (2012) 42, pp. 540-563, Mara J. Goldman, Paul Nadasdy and Matthew D. Turner (eds.), Knowing Nature: Conversations at the Intersection of Political Ecology and Science Studies, Chicago: The University of Chicago Press, 2011, Estelita Vaz, Cristina Joanaz de Melo and Lígia M. Costa Pinto (eds.), Environmental History in the Making, 2 vols., Cham: Springer, 2016.

31 Madeleine Ly-Tio-Fane, Mauritius and the Spice Trade: The Odyssey of Pierre Poivre, Port Louis: Esclapon, 1958, Ly-Tio-Fane, Mauritius and the Spice Trade: The Triumph of Jean Nicolas Céré and His Isle Bourbon Collaborators, Paris and The Hague: Mouton and Company, 1970. See also Olivier Le Gouic, 'Pierre Poivre et les épices: une transplantation réussie', in Sylviane Llinares and Philippe Hrodej (eds.), Techniques et colonies (XVIe-XXe siècles), Paris: Publications de la Société française d'histoire d'outre mer et de l'Université de Bretagne Sud-SOLITO 2005, pp. 103-126; Louis Malleret, Pierre Poivre, Paris: AdrienMaisonneuve, 1974; Denis Piat, L’île Maurice: sur la routes des épices, 1598-1810, Paris: les Éd. du Pacifique, 2010. 
(hereafter the VOC), sought to defend their monopoly of the spice. ${ }^{32}$ The islands were largely closed to French vessels, and French actors had to rely on a secret Indo-Pacific island network consisting of local populations for the acquisition of plant material.

The attempt to establish a spice trade with Asia started in the late 1740s under the administration of the CIO. ${ }^{33}$ Already by 1748 , Pierre Poivre proposed to the CIO to collect spices in different parts of the world. A lengthy enterprise began in which, initially, Poivre did not possess much credibility and was in the same position as the numerous speculators who sought financial support for very uncertain enterprises. ${ }^{34}$ When nutmeg and other spices were imported, their introduction into the island's economy remained minimal and unsystematic due to conflicting political agendas of colonial administrators and an overall CIO lack of interest in economic botany on Isle de France and the projects of individuals rather than administrators. These circumstances were fuelled by environmental difficulties and the rivalry between Poivre and the naturalist Jean Baptiste Christophore Fusée-Aublet (1720-1778). ${ }^{35}$ Moreover, the lack of success and ongoing complications in transporting nutmeg and clove from the Maluku islands to Isle de France encouraged the French to begin looking for spice substitutes. ${ }^{36}$ It was only after the Treaty of Paris ended the Seven Years War in 1763 that French officials rediscovered the potential value of the nutmeg that was to give the remote Isle de France a financial boost and break the Dutch monopoly of this spice. ${ }^{37}$

Commercial visions, however, faced colonial and environmental reality. The acclimatization of new crops required understanding the plants' needs and the island's ecosystem. ${ }^{38}$ In the plants' new home (Isle de France), the nutmeg faced climate and soil conditions which were different from those of its native South East Asian islands. Not every plant had the same agricultural requirements; each plant needed specific knowhow that had to adapt to the island's environmental conditions. Knowledge was not-and is not-static, but produced, appropriated and transformed according to

32 Merle C. Ricklefs, A History of Modern Indonesia since c.1200, 4th edn, Houndmills: Palgrave Macmillan, 2008, pp. 69-71, Leonard Y. Andaya, 'Local trade networks in Maluku in the 16th, 17th, and 18th centuries', Cakalele: Maluku Research Journal (1991) 2, pp. 71-96; and Andaya, The World of the Maluku: Eastern Indonesia in the Early Modern Period, Honolulu: University of Hawaii Press, 1993.

33 Emma C. Spary, 'Of nutmegs and botanists: the colonial cultivation of botanical identity', in Schiebinger and Swan op. cit. (7), pp. 187-203. On the CIO see, for instance, Philippe Haudrère, La compagnie française des Indes au XVIIIe siècle, 2nd edn, Paris: Indes savantes, 2004; and Haudrère, Les français dans l'océan Indien, XVIIe-XIXe siècle, Rennes: Presses universitaires de Rennes, 2014.

34 See Dorit Brixius, 'A pepper acquiring nutmeg: Pierre Poivre, the French spice quest and the role of mediators in Southeast Asia, 1740s to 1770s', Journal of the Western Society for French History (2015) 43, pp. 68-77.

35 Spary, op. cit. (33).

36 The search for imitation spices was common in the early modern world. For the Portuguese context see Alírio Cardoso, 'Especiarias na Amazônia Portuguesa: Circulação Vegetal e Comércio Atlântico no Final da Monarquia Hispânica', Tempo (2015) 21, pp. 116-133, 118. See also Matthew P. Romaniello, 'True rhubarb? Trading Eurasian botanical and medical knowledge in the eighteenth century', Journal of Global History (2016) 1, pp. 3-23. On Poivre's idea to introduce ravensara as a subsitute for nutmeg and clove see 'Observations sur le muscadier', Archives nationales d'outre-mer Aix-en-Provence (subsequently ANOM) Col C/2/285, fol. 158 .

37 Ly-Tio-Fane, The Odyssey of Pierre Poivre, op. cit. (31); Le Gouic, op. cit. (31); Brixius, op. cit. (34).

38 See also Margócsy, Commercial Visions, op. cit. (22); Cook, op. cit. (20). 
certain environments and according to the purpose for which it was used. Knowledge practices rooted in European and Indo-Pacific (including both African and Asian) traditions clashed or merged when applied to the island's ecological context. Hence cultivation on Isle de France produced a complex creolization of expertise that originated from the local populations of the plants' native islands and was then reconfigured through the horticultural knowledge of colonists, settlers, labourers and slaves living on the colonial island. Here, when looking at the multiplicity of all different practices of Indo-Pacific origins that came together in an island space, European knowledge was in profound crisis because it had very limited value in the island's context.

Attempting to acclimatize nutmeg between 1768 and 1772, Poivre, now Isle de France's intendant, initiated several expeditions to the Maluku islands, led by the navy officer Jean Mathieu Simon Provost. ${ }^{39}$ These expeditions to the islands were top secret. Though partially funded by the Crown, they were locally initiated. As Isle de France's local administration struggled with funding, its administrators were consequently reliant on personal favours, communication, trust and alliances with islanders spanning an Indo-Pacific island network. ${ }^{40}$ These networks extended all over the Indo-Pacific, involving French, Filipino, Maluku, Malay, Dutch, Spanish and Portuguese agents, and more. ${ }^{41}$ They were determined by spontaneous possibilities and carried out by intermediaries who often secretly traded nutmeg in different parts of South East Asia. Relying on an extensive web of local islanders in the Malay world, specimen acquisition and transport were endlessly entangled and driven by actors who were not formally trained in natural history. ${ }^{42}$ The nutmeg project was made possible because of the great assistance of Malay go-betweens and Maluku islanders who had access to plant material in Dutch territory, otherwise inaccessible to the French. ${ }^{43}$ Finally, after more than two decades had passed since the first attempts in the late 1740s, the nutmeg arrived in sufficient quantities for experimentation on the island in $1772 .{ }^{44}$

39 On Poivre and his time as intendant see Grove, op. cit. (9); Stockland, op. cit. (30); Roberts, op. cit. (15); Madeleine Ly-Tio-Fane, 'Problèmes d'approvisionnement de l'Ile de France au temps de l'intendant Poivre', Proceedings of the Royal Society of Arts and Sciences Mauritius (1968) 3, pp. 101-115.

40 Sarah Easterby-Smith, 'Reputation in a box: objects, communication and trust in late 18th-century botanical networks', History of Science (2015) 53, pp. 180-208. See also Šebestián Kroupa, 'Ex epistulis Philippinensibus: Georg Joseph Kamel SJ (1661-1706) and his correspondence network', Centaurus (2015) 57, pp. 229-259; John McAleer, “"A young slip of botany”: botanical networks, the South Atlantic, and Britain's maritime worlds', Journal of Global History (2016) 11, pp. 24-43.

41 See Brixius, op. cit. (34).

42 On this claim see also, for instance, Kroupa, op. cit. (40); Easterby-Smith, op. cit. (40).

43 For a few examples in relation to the collection of plant knowledge and material see Richard Grove, 'Indigenous knowledge and the significance of south-west India for Portuguese and Dutch constructions of tropical nature', Modern Asian Studies (1996) 30, pp. 121-143; Ines G. Zupanov and Ângela Barreto Xavier, 'Quest for performance in the tropics: Portuguese bioprospecting in Asia (16th-18th centuries)', Journal of the Economic and Social History of the Orient (2014) 57, pp. 511-548; Christopher M. Parsons, 'Plants and peoples: French and indigenous botanical knowledges in colonial North America, 1600-1760', $\mathrm{PhD}$ thesis, University of Toronto, 2011; Minakshi Menon, 'Making useful knowledge: British naturalists in colonial India, 1784-1820', PhD thesis, University of California, 2013.

44 Commerson's report, 8 June 1772, ANOM Col C/4/30, fol. 303r; and report by Adanson and Jussieu, 17 February 1773, les archives de l'Académie des sciences, Paris, Procès-verbaux 1773, fols. 32v-37r. 


\section{Cultivation, people, environment and the adaptation of techniques}

In this section, I focus on the complex process of acclimatizing nutmeg on Isle de France alongside the introduction of knowledge and people that sometimes accompanied it. It all started with the dangerous and costly transport of specimens and seeds from the Maluku islands to Isle de France. The existing methods of preserving curiosities and specimens increasingly proved insufficient; all too often, specimens transferred across oceans arrived damaged. ${ }^{45}$ Implementing instructions was a difficult task, and even when they were followed correctly they by no means guaranteed success. As Nigel Rigby has written about the transport of scientific specimens in the eighteenth-century Pacific, 'The failure rate in all these methods was high. ${ }^{46}$ So too was the failure rate of cultivation using the theoretical knowledge of metropolitan experts.

On Isle de France in the 1770s, the nutmeg did not reproduce in the same way as administrators envisioned it. Acclimatization was a matter of successfully explaining and acting: explaining the plants' needs and mastering appropriate techniques to act on them. The inability to understand the plants' needs conditioned cultivation: on the one hand, the nuts (the seeds) had (and have) to be planted almost immediately after their harvest because they lose their ability to bud after only about a week. ${ }^{47}$ Indeed, purchasable nuts do not germinate and Maluku people used to believe that human hands could not propagate the nutmeg because of the difficulty of human-assisted reproduction. ${ }^{48}$ In order to give Isle de France a financial boost, contemporaries would have needed huge quantities of nuts that could have been sold on the Asian market. Yet the quantity of nuts remained limited throughout this period.

The marine officer Provost was aware of the potential value of embodied knowledge, and he encouraged the transport of knowledgeable people from South East Asia to Isle de France. For the cultivation of nutmeg, he had two Creole young men from the Maluku islands, one of whom was of French ancestry, come to Isle de France. He hoped that they

45 Christopher M. Parsons and Kathleen S. Murphy, 'Ecosystems under sail: specimen transport in the eighteenth-century French and British Atlantics', Early American Studies (Fall 2012) 10, pp. 503-539; Nigel Rigby, 'The politics and pragmatics of seaborne plant transportation, 1769-1805', in Margarette Lincoln (ed.), Science and Exploration in the Pacific: European Voyages to the Southern Oceans in the Eighteenth Century, Rochester: Boydell Press, 1998, pp. 81-100; Marianne Klemun, 'Introduction: "moved” natural objects - "spaces in between"', Journal of the History of Science and Technology (2012) 5, pp. 9-16; Jim Endersby, Imperial Nature: Joseph Hooker and the Practices of Victorian Science, Chicago: The University of Chicago Press, 2008; Anne Mariss, 'A World of New Things': Praktiken der Naturgeschichte bei Johann Reinhold Forster, Frankfurt am Main: Campus Frankfurt, 2015; Daniela Bleichmar, 'Atlantic competitions: botany in the eighteenth-century Spanish Empire', in James Delbourgo and Nicholas Dew (eds.), Science and Empire in the Atlantic World, New York: Routledge, 2008, pp. 225-252; Marie-Noëlle Bourguet, 'Measurable difference: botany, climate, and the gardener's thermometer in eighteenth-century France', in Schiebinger and Swan, op. cit. (7), pp. 270-286.

46 Rigby, op. cit. (45), p. 84.

47 'Description abrégée du muscadier et du géroflier pour servir à mettre les Srs Trémigon et Provost dans le cas de n'être pas trompés dans le choix des plants de ces deux espèces d'arbres', by Poivre, ANOM Col C/4/22, fol. 127r. All translations are made by the author unless otherwise indicated.

48 K.P. Funke, 'Muskatnüsse', Magazin Der Handels- und Gewerbskunde (1805) 7, 72. See also Georgius Everhardus Rumphius, Herbarium Amboinense/Het Amboinsch Kruid-Boek, Amsterdam: Meinard Uytwerf, 1750, vol. 2, Chapter 4, p. 20. 
could assist with the cultivation of spices even though they seemingly had not worked as cultivators on the Maluku islands. Indeed, once on Isle de France, it turned out that the two young men did not possess extensive agricultural knowledge and were blamed for overwatering young plants. ${ }^{49}$ It was (and remains) misleading to assume that because these individuals lived on an island where native nutmeg was cultivated, they would be familiar with the appropriate technologies. One could also imagine that forced migration and homesickness left these islanders utterly uninterested in tending to the needs of a similarly dislocated plant.

Contemporary observers (and rivals) claimed that Poivre considered too many men incapable of treating the needs of the plants. ${ }^{50}$ One exception was Charles Rama, an enslaved Bengali who possessed the requisite agricultural knowledge to skilfully cultivate nutmeg and worked as head gardener in Poivre's private acclimatization garden. ${ }^{51}$ Rama's labour in the garden demonstrated that the embodied knowledge necessary to cultivate nutmeg came to Isle de France not necessarily from South East Asian islands but from the South Asian mainland. Indeed, slave cultivators came from many parts of the world, including Madagascar, the African mainland, and also parts of Asia. ${ }^{52}$ French settlers were in great need of tropical agricultural knowledge and skills because as Poivre argued already in the 1750s while he travelled in the Indo-Pacific - although the most capable settlers on Isle de France were those with knowledge about European agriculture, this knowledge was not suitable for the tropical island. ${ }^{53}$ Back then, Poivre claimed that there was not one capable man on the island with knowledge about the treatment of spices. Further, he affirmed that European settlers lacked the patience, diligence and dedication necessary to the cultivation of foreign plants that could be of interest to the French kingdom but which did not promise immediate profit. $^{54}$

Europeans possessed only rudimentary knowledge about the natural world outside Europe and the 'exotic' was frequently constructed from insufficient information. ${ }^{55}$

49 Poivre to Praslin only, 22 August 1771, ANOM Col C/4/29, fols. 22v-23r.

50 Galloys to Praslin, 14 August 1769, ANOM Col E 197, unfol.

51 'Objections de Rama, jardinier noir esclave de l'habitation de Monplaisir, au mémoire de Pierre Poivre' (pamphlet by Jacques Maillard-Dumesle), 12 August 1774, Archives départementales Eure et Loire, Fonds Grandet-Bailly $15 \mathrm{~J} \mathrm{11;} \mathrm{'Liste} \mathrm{des} \mathrm{noirs} \mathrm{de} \mathrm{l'habitation} \mathrm{de} \mathrm{Monplaisir',} \mathrm{n.d.,} \mathrm{possibly} \mathrm{1772,} \mathrm{Mauritius}$ Archives (subsequently MA) OA 127, no 42; 'Registre pour servir à l'enregistrement des actes de liberté accordée à des esclaves', 29 December 1768-5 February 1785, MA OA 75, entry on Rama, p. 135. Indeed, the latter document is very explicit that Rama was emancipated because of his skills and the great work he had done for the cultivation of spices.

52 Vaughan, op. cit. (8).

53 Poivre to Jacques-Marie-Jérôme Michau de Montaran (1701-1782), co-president of the CIO secret committee, 10 January 1754, ANOM Col C/4/8, Letter 20.

54 Poivre to Montaran, op. cit. (53).

55 For examples about confusion and misinterpretation in other contexts see Samir Boumediene, La colonisation du savoir: Une histoire des plantes médicinales du Nouveau Monde (1492-1750), Vaulx-enVelin: Des mondes à faire, 2016, pp. 185-214, in particular 191-194, 207-213. Šebestián Kroupa has argued a European lack of effort of using the precise name of a plant in the context of the seventeenthcentury Spanish Philippines: Šebestián Kroupa, 'Georg Joseph Kamel (1661-1706): a Jesuit pharmacist in Manila at the borderlines of erudition and empiricism', unpublished manuscript, pp. 11-12, by permission 
Already in 1754, Poivre promoted himself as somebody able to provide this information. Isle de France, he claimed, was in need of a man who had travelled in the tropical climates of the Indies, which were similar to that of the island; the island needed someone who was familiar with the ways of agriculture practised by the inhabitants of such climates. ${ }^{56}$ Certainly, as he argued, the island had no need for someone who had only experienced Europe and who thought they could cultivate nutmeg on Isle de France 'like horse chestnut in France' ${ }^{57}$ Poivre was aware that plants had different environmental requirements and that this changed the way that people engaged with them. Tropical plants in tropical climates required specialized knowledge and a different treatment than European plants cultivated by using European agricultural methods in France. In seeking to find a scapegoat, Poivre complained that the main reason for the lack of success of the spice project was colonists' impatience. He argued that sprouting nuts were planted with too much strength in the ground and, as a result, both small sprouts rising through the soil and taproots were accidentally destroyed. Because many nuts were placed too deeply in the ground, they only showed signs of germination after ten or eleven months. ${ }^{58}$

It remains unclear how cultivators were instructed during the first attempts at acclimatization. Yet we do know that, prior to Poivre's departure in 1773, he printed and circulated 'Instruction sur la manière de planter et de cultiver avec succès les plantes et les graines de Géroflier et de Muscadier' (Instruction on the manner of successfully planting and cultivating plants and seeds of clove and nutmeg) to local colonists. ${ }^{59}$ These instructions were likely based on Poivre's own observations made on the Maluku islands in 1752 as well as those of Provost during the 1771-1772 spice quests. ${ }^{60}$ Poivre embraced the knowledge and agricultural practices of two important Malaku islands, Ambon and Banda, which he had gathered while travelling in the Indo-Pacific around $1750 .{ }^{61}$ Poivre also drew knowledge from other written sources related to the cultivation of Maluku spices. In particular, he extracted knowledge from the Dutch naturalist G.E. Rumphius's Het Amboinsch Kruid-Boek, which was the first account of nutmeg in Dutch territory and, in particular, on Ambon. ${ }^{62}$ Het Amboinsch Kruid-Boek was

of the author. I thank Šebestián for providing a copy of his unpublished work. See also Natalie Lawrence, 'Assembling the dodo in early modern natural history', BJHS (2015) 48, pp. 387-408.

56 Poivre to Montaran, op. cit. (53).

57 Poivre to Montaran, op. cit. (53).

58 Poivre to Montaran, op. cit. (53).

59 'Instruction sur la manière de planter et de cultiver avec succès les plantes et les graines de géroflier et de muscadier', 1772, Archives nationales Paris (subsequently AN), MAR G101, File 4, fols. 171v-175r.

60 'Observations sur le muscadier et principalement sur la culture de cet arbre', Manila, 12 February 1752, ANOM Col C/2/285, fols. 158r-162v, 'Instruction sur la manière ...', Bibliothèque centrale du Muséum d'histoire naturelle Paris (subsequently BCMNHN) Ms 280, vol. 1, unfol.,

61 This is what Poivre explains to Minister Praslin, 16 June 1768, ANOM Col C/4/22, Letter 66.

62 Georgius Everhardus Rumphius, The Ambonese Herbal: Being a Description of the Most Noteworthy Trees, Shrubs, Herbs, Land-and Water-Plants Which Are Found in Amboina and the Surrounding Islands according to Their Shape, Various Names, Cultivation, and Use, Together with Several Insects and Animals (ed. Eric Beekman), New Haven, CT: Yale University Press, 2011. Rumphius actually came to Ambon as an employee of the VOC and relied on the crucial intermediation of his wife and a larger Maluku island network. On Rumphius's mediators see Genie Yoo's essay in this special issue. See also Matthew Sargent, 
translated into Latin as Herbarium Amboinense (1750), yet the circulation and editions of the book are still a matter of further research. ${ }^{63}$ Het Kruid-Boek (or rather the Dutch and Latin edition) became an important point of reference for naturalists both in France and overseas. It is unknown to which edition Poivre had access but actors in Paris surely consulted the 1750 Dutch and Latin edition, on which I elaborate in the remaining sections. ${ }^{64}$

Poivre's instructions underlined that cultivating a plant did not happen in isolation but instead required an interactive environment where plants helped each other. It was in Poivre's studies of plants in other settings that he began to imagine an environment for the nutmeg trees, which accounted for the available human and environmental resources on Isle de France. Precise precautions were necessary to ensure freshness, shade and protection against the cyclones that were frequent in the south-west Indian Ocean. ${ }^{65} \mathrm{He}$ elaborated in particular on how different kinds of plants could be used to cast just the right amount of shade and wind protection to facilitate proper protection and reproduction. When constructing an appropriate orchard, for example, one was to choose a piece of land protected by a hedge of bamboo as the surrounding outer row. For the second row after the hedge, one was to choose trees such as the mango, the jackfruit or the betel or coconut palm, and, in a third row, trees such as the orange, lemon, cinnamon, or coffee. ${ }^{66}$ Like the nutmeg, these plants were also not native to Isle de France and contemporaries tested transplanted crops for how they could be integrated in a new ecosystem.

Methods of cultivation were learned through experience with creolized ecosystems. In order to ensure that spice seedlings were protected against the wind and too much sun, Poivre recommended planting them together with banana trees, which could provide shade and hold off the strong winds. ${ }^{67}$ In the later 1770s, the experience with clove (which was also introduced from the Maluku islands) showed, however, that banana trees proved to be the wrong sort of tree because they provided too much shade. ${ }^{68}$ Prior to this, instructions to colonists (possibly dated 1771/1772) underlined that the banana tree was very suitable for cinnamon (which possibly came from the island of Ceylon, now called Sri Lanka) because it required much shade. Clove seedlings were likewise to be protected from the burning sun by the placement of small leaves such as those

'Global trade and local knowledge: gathering natural knowledge in seventeenth-century Indonesia', in Tara Alberts and David Irving (eds.), Intercultural Exchange in Southeast Asia: History and Society in the Early Modern World, London: I.B. Tauris, 2013, pp. 144-160. On how Poivre uses Rumphius see 'Observations sur le muscadier et principalement sur la culture de cet arbre', Manila, 12 February, 1752, ANOM Col C/2/ 285 , fols. $158 \mathrm{r}-162 \mathrm{v}$.

63 For instance, see ongoing research by a group of scholars at the University of Cologne, Germany, at https://rumphius.hypotheses.org, accessed 29 April 2018.

64 Report by Adanson and Jussieu, op. cit. (44).

65 On cyclones in the south-west Indian Ocean and Mauritius under British rule see Martin Mahony's essay in this special issue. See also Grove, op. cit. (9).

66 Report by Adanson and Jussieu, op. cit. (44).

67 Report by Adanson and Jussieu, op. cit. (44).

68 Instructions for the cultivation of the clove tree, by Céré, 7 April 1779, transcribed in Ly-Tio-Fane, The Odyssey of Pierre Poivre, op. cit. (31), p. 128. 
of the tamarind. ${ }^{69}$ As these instructions emphasized, horticulturalists were encouraged to experiment with what worked best for different spice plants only newly brought together. ${ }^{70}$ Ultimately, cultivators had to take care that the protecting plants did not harm the nutmeg. One had to ensure, for example, that introduced bamboo grew in the direction of the hedge instead of spreading towards the middle parts where the nutmeg was planted. ${ }^{71}$

Working the soil was another important facet of colonial cultivational techniques. Nutmeg required 'fat' and humid soil. ${ }^{72}$ After stirring it, one was to enrich it by using 'some other materials suitable as amendment', such as leaves. Although the soil on Isle de France seemed fertile, Poivre provided several justifications for the use of improvements. For instance, when the soil became too dry, it was too sticky and required loosening so that water could flow more easily. ${ }^{73}$ The nutmeg was to be sown in the rainy season, which was at a different time of the year on Isle de France than on the Maluku islands. According to the 'gifted gardeners of Banda' that Poivre may have observed himself when travelling - and surely extracted from Het Kruid-Boek since he used it as a reference point in the production of his own document - it was better to plant the seeds as much as two months before the rains because then the nut could germinate and therefore take root prior to the resulting humidity. ${ }^{74}$ In this way, the nut could also develop its stalk more easily once the rain came. Otherwise, the young plants could easily perish when 'drowned' in water.

Once the field was prepared, the appropriate placement of the nutmeg was likewise important. When germinating, all plant seeds always develop a small root first that will allow the seed to develop a stem. This knowledge, however, was not common to settlers who had little experience with agriculture. Even though exact methods of placing the nut in the soil were meticulously detailed, they were nonetheless misinterpreted. According to the instructions, the plant required a bed of two to three feet of 'clean' earth, which was not to contain compost. An accompanying drawing demonstrated that nutmeg, partially germinated, should be planted horizontally, with the long and thick downside in the soil. ${ }^{75}$ A fully germinating nut was to be planted as follows: one was not to put the entire nut deep into soil. Instead, only the small root was to be put into soil, and the nut was to be covered only lightly with foliage. ${ }^{76}$ The document explained that some settlers mistreated the germinating seeds because they confused the small root with the developing stem. Consequently they planted it upside down; that is to say, with the root on top and the developing stem in the soil. ${ }^{77}$ This only led

69 'Instruction', op. cit. (60).

70 'Instruction', op. cit. (60).

71 'Instruction', op. cit. (60).

72 'Observations sur le muscadier', ANOM Col C/2/285, fol. 159r.

73 'Instruction', op. cit. (60).

74 'Observations', op. cit. (72).

75 'Instruction', op. cit. (60).

76 'Instruction', op. cit. (60).

77 'Instruction', op. cit. (60). 
to the nuts' perishing. Despite the most precise instructions possible, mistakes were frequent, due to either ignorance, a lack of experience, carelessness or misinterpretation.

Two things were definitively required when growing nutmeg: cultivational know-how and, above all, patience. While trees were maturing, the influence of the climate remained an omnipresent factor. In the report of Jean Nicolas Céré (1737-1810), who became head gardener of the royalized Jardin des pamplemousses after Poivre's departure in 1773, the naturalist underlined how cyclones damaged or even uprooted young plants, and described plagues of rats, which led to the loss of the biggest 'creole' tree (as Céré called it) in 1779. ${ }^{78}$ Moreover, on 4 November 1783, Céré's report about the cultivation of spice plants explained that two nutmeg trees died because of a vase mortière around their roots. Bad soil or mud might have harmed them and caused them to perish. ${ }^{79}$ Colonial ecosystems were fragile and trees easily lost.

From their beginnings, French attempts to acclimatize nutmeg were tentative and experimental. Appreciating the complications of environmental factors and the right manner of cultivation were central to the project. Cultivation methods, rooted in Maluku experience, European systems and techniques, and African and Malagasy ethnobotanical knowledge that travelled with the immense slave population, had to be heavily adapted to the island's ecosystem. This required understanding the plant, its cultivation and the soil and climatic conditions. Acknowledging the creolized knowledge that produced Isle de France's nutmeg, we can reveal the creolization of cultivational practices that adapted to environmental factors (including rain, sun and storms), the island's soils and horticultural techniques.

\section{Maluku classification in transit - or how to make sense of botanical plurality around $\mathbf{1 7 7 0}$}

Understanding how French actors tried to make sense of Maluku classification systems is important in order to understand the contemporary confusion about the identity of the nutmeg that rooted in European interpretation, which led to generalization. When making sense of botanical plurality, a part of creating generalized and universal knowledge in taxonomy dismissed the complexity of the Maluku world. It becomes particularly evident through language that this complexity was erased through summary, translation and descriptions that came from a different view of the nutmeg.

Historians have shown that there was persistent confusion about the different kinds of nutmeg among French historical actors. For example, Emma Spary has discussed the confusion and identity building of the 'true' nutmeg on Isle de France in the 1750s as the source of an immense dispute between Poivre and Fusée-Aublet. ${ }^{80}$ The essential problem in the later 1770 s and the 1780 s, however, was not the different species of

78 Céré's report on the cultivation of spice plants, 4 November 1783, transcribed in Ly-Tio-Fane, The Odyssey of Pierre Poivre, op. cit. (31), p. 109. On climate and colonial attempts see Anya Zilberstein, A Temperate Empire: Making Climate Change in Early America, New York: Oxford University Press, 2016.

79 Céré's report on the cultivation of spice plants, 4 November 1783, transcribed in Ly-Tio-Fane, The Odyssey of Pierre Poivre, op. cit. (31), p. 109.

80 Spary, op. cit. (33). 
nutmeg and the discussion of 'true' or 'false'. Rather, recognition of nutmeg's different sexes led to both misinterpretation and increasingly practical challenges to reproduction. In other words, even while the French drew on Maluku classification as a source of knowledge - partly via Het Kruid-Boek - this knowledge created a tension between theory and the practical needs of cultivators.

A 1773 report produced by Parisian naturalists that concerned nutmeg specimens sent from the Indian Ocean showed how actors on Isle de France sought to make sense of the plurality of Maluku classification. ${ }^{81}$ According to this report, Poivre had sent a letter, together with the specimens, to Paris for examination. Although I have been unable to locate this letter in the French or Mauritian archives, the academy's report opens a window onto the transfer of Maluku knowledge to Isle de France, where it was accumulated and appropriated.

The metropolitan botanists Michel Adanson and Bernard de Jussieu examined three different kinds of nutmeg, which had been sent from Isle de France to the Académie royale des sciences. ${ }^{82}$ The naturalists officially approved the authenticity, value and commercial quality of the nutmeg plants and clove trees that Poivre's collaborators had gathered on the Maluku islands. ${ }^{83}$ Poivre used the expert judgement of the academy's members in order to turn their findings into official knowledge and policy. ${ }^{84} \mathrm{He}$ needed to publicize his claim of having introduced the 'true' nutmeg after several decades of uncertainty, and he pursued the Academy's approval and scientific justification in the hope of official recognition. ${ }^{85}$ The purpose of this report was as political as it was botanical.

According to Adanson and Jussieu's report, specimens were sent in glass containers filled with alcohol that were numbered and labelled with Malay names. They contained mostly fruits without branches and were labelled 'Pala parampuan', 'Pala lakki-lakki' and 'Pala Lakki Parampuan'. ${ }^{86}$ These names, however, are absent from the Dutch and Latin edition of Rumphius's Kruid-Boek, upon which Parisian naturalists and Poivre (when it had served him as a source of knowledge already in the 1750 s) relied. ${ }^{87}$ Instead, when sending specimens in 1772, somebody - possibly Poivre himself - provided these three names on the flasks, drawn from Maluku sources during the several spice quests conducted by Poivre and Provost.

81 Report by Adanson and Jussieu, op. cit. (44), fol. 32v. Neither in the archives of the French Academy and the BCMNHN nor in AN was I able to find any surviving documents in relation to Ambonese taxonomy, or the distinction of nuts more generally, dated to 1772 when the specimens, together with Poivre's letter, must have been sent.

82 Report by Adanson and Jussieu, op. cit. (44), fol. 32v-37r.

83 Report by Adanson and Jussieu, op. cit. (44), fol. 32v-37r.

84 On this point see also Fredrik Albritton Jonsson, Enlightenment's Frontier: The Scottish Highlands and the Origins of Environmentalism, New Haven, CT: Yale University Press, 2013, p. 125.

85 On voyages and scientific discourse see also Sophie Linon-Chipon and Daniela Vaj (eds.), Relations savantes: Voyages et discours scientifiques, Paris: Presses de l'Université Paris-Sorbonne, 2006.

86 Report by Adanson and de Jussieu, op. cit. (44), fol. 32v.

87 Compare their report to Rumphius, op. cit. (48), vol. 2, pp. 14-18, 24-29. For the English translation see Rumphius, op. cit. (62). 
As French actors only relied on the seemingly dominant terms for the nutmeg in Bahasa Malay widely spoken in island South East Asia, the complexity of the linguistics and botanical knowledge of the region was reduced, simplified and generalized. ${ }^{88}$ Pala in Bahasa Malay indeed means 'nutmeg', and was used as the overall term for that spice. The Malay terms were the dominant expressions that travelled from the Maluku islands to Isle de France, and which local actors forwarded to Paris, naming the female nutmeg 'Pala parampuan', the female and long nutmeg 'Pala Lakki Parampuan' and the 'wild' male or long nutmeg 'Pala lakki-lakki'. ${ }^{89}$ In Bahasa Malay, discussion of the sex of the plant was embedded within these naming practices, showing the distinction between female and male: in Malay, perempuan means 'female' or 'woman' and both words laki and laki-laki mean 'man' or 'male'. Moreover, laki means 'long', perhaps in relation to the symbol of the phallus. ${ }^{90}$

Whereas in Paris misinterpretation might have led only to theoretical debates, on Isle de France they created practical challenges for cultivators. The most crucial misinterpretation amongst Parisian actors relates to the fact that Rumphius referred to the distinction between male and female trees and not - as the metropolitan botanists seemed to have assumed - to the nuts as such. In other words, Rumphius and the cultivators of Isle de France classified the sexuality of nutmeg by referring to the obvious differences of the trees. Parisian botanists - who had never seen a nutmeg tree in reality - worked from Het Kruid-Boek and instead looked at the nuts for their classificatory data when examining the specimens. They were so fixated on the seed specimens that they neglected to consider the plants as wholes. Finally, one must also consider the question of priorities and purpose: the metropolitans' classification was based on the commodity, to make sense of it, while the colonists' classification was possibly based on the parts of the plant they worked with to make it grow. In that sense, this case also illustrates the disruption of knowledge transmission between the Maluku islands and Isle de France up to Paris.

By the same token, in Het Kruid-Boek (and its Latin translation), Rumphius provided Malay names that might have had a different meaning in local Maluku languages and

88 Bahasa Malay was widely spoken in the Maluku world and served, besides Portuguese and Dutch, as lingua franca in that part of the world. On Bahasa Malay see Rachel Leow, Taming Babel: Language in the Making of Malaysia, Cambridge: Cambridge University Press, 2016. On language and negotiation in the early modern world see Dejanirah Couto and Stéphane Péquignot (eds.), Les langues de la négociation: Approches historiennes, Rennes: PUR, 2017.

89 Report by Adanson and Jussieu, op. cit. (44), fols. 35r-36r.

90 There are few studies on difficulties attending the use of native names, although primarily with respect to the gap between European and colonial situations: Endersby, op. cit. (45). See also David Gledhill, The Names of Plants, Cambridge: Cambridge University Press, 2008; Scott Atran, Cognitive Foundations of Natural History: Towards an Anthropology of Science, Cambridge: Cambridge University Press, 1999; Clifford Geertz, 'Common sense as a cultural system', Antioch Review (1975) 33, pp. 5-26. For exciting research on Victorian botany and Māori and Polynesian plant names see Geoff Bil, 'Between Māori and modern? The case of mānuka honey', in Elisabeth Kapferer, Andreas Koch and Clemens Sedmak (eds.), Appreciating Local Knowledge, Newcastle upon Tyne: Cambridge Scholars Publishing, 2016, pp. 61-76; and Bil, 'Ambivalent ethnobotany: John Buchanan and Māori plant knowledge in imperial context', in Linda Tyler and David Galloway (eds.), Art in the Service of Science: Dunedin's John Buchanan, 1819-1898, Dunedin: University of Otago Press (in press). 
were by no means used everywhere. Local Maluku classificatory nomenclature differed significantly from one island to another, which were nonetheless otherwise closely connected. Rumphius's account provided Maluku names for wild nutmeg and distinct local classifications used on different islands: the Malay pala laki-laki (meaning male or wild nutmeg) was considered by the inhabitants of Banda pala fuker, which meant 'mountain nutmeg'. ${ }^{91}$ On Ambon, however, this species was considered pala utan and palala, the latter being a combination of pala and ala. Ala was the name of a nutmeg-eating bird, possibly today's Blyth's hornbill. ${ }^{92}$ Seemingly, it is the same bird that the Bandanese called falour, which was called burong pala by the Malay. ${ }^{93}$ Overall, however, Rumphius explained that the pala laki-laki bore fruit. It might therefore have been possible that the wild nutmeg and inferior types were always considered to be male and the true and superior nutmegs were called female in the first place (with recognition nonetheless that there were male trees), because other Maluku names actually do not make a reference to a tree being either male or female. The Malay names referred to sex, in Bandanese they referred to the place of occurrence, and in Ambonese the name makes reference to the nutmeg-eating bird.

In Het Kruid-Boek, Rumphius - who was aware of local taxonomic diversity - documented local knowledge systems of the second half of the seventeenth century that were completely ignored by French actors both in the Indo-Pacific and in Paris. The French on Isle de France and in Paris might have misinterpreted Ambonese classification in the first place: the Ambonese grouped the trees according to fruit-bearing (female) and non-fruitbearing (male) trees and the names do not refer to the nuts, as French actors seemingly assumed. These examples reveal the incredibly complex world of the Maluku islands of which French actors, however, were not aware. While Poivre had clearly drawn on Rumphius in his descriptions of nutmeg cultivation, classificatory nuances were omitted. It was in the documentation of such taxonomic difference that clues about the species and their relationships were hidden, seemingly because Poivre misinterpreted them or set different priorities. Even while Rumphius provided a complex description of Maluku classificatory schema in Het Kruid-Boek, it was taken into account neither by Poivre nor by metropolitan naturalists.

Yet Rumphius's description of the Maluku classificatory schema serves as important evidence that the sex of plants was commonly accepted in the seventeenth-century Maluku world - and therefore much earlier than in France. Different peoples in different contexts divide their natural environment into units, such as cultivators who recognized the plants' sex and the practical challenges that came with such recognition. As Stephen Jay Gould put it once, 'In short, the same packages are recognized by independent cultures.' ${ }^{94}$ Classification systems, whether framed as farmer knowledge or folk taxonomy, should not be understood as a lesser form of knowledge than botany and science seek to be. European knowledge was only one type of knowledge and had significant limitations

91 Rumphius, op. cit. (48), vol. 2, p. 24.

92 Rumphius, op. cit. (62), vol 2, p. 37, margins.

93 Rumphius, op. cit. (48), vol. 2, p. 20.

94 Stephen Jay Gould, The Panda's Thumb: More Reflections in Natural History, New York: Norton, 1980, p. 207. 
even as it borrowed from other systems. In the case of nutmeg, taxonomic knowledge rooted in European traditions did not produce any benefits in the colonies.

\section{Histoire naturelle in action and the challenges of sex in plants}

The crucial aim of the commercial visions of acclimatizing foreign species was abundant plant reproduction. On Isle de France this was never actualized. Through the process of acclimatization, local cultivators on Isle de France became increasingly aware of the challenges of plant breeding. This final section analyses the process of recognizing these challenges, how contemporaries sought to make sense of them while drawing on Maluku knowledge, and how they eventually sought to overcome them by the initiation of a slave.

The discovery of plant sexuality was only slowly accepted in France and, as Antoine Jacobsohn has argued, at the turn of the nineteenth century created a tension between the botanical identification of new species, cross-pollination and the practical needs of farmers. ${ }^{95}$ Yet scholars have suggested that the sexual system of classification was largely ignored before this. ${ }^{96}$ Therefore the sexuality of plants was likely not acknowledged in the middle decades of eighteenth-century France nor in the colonial Indian Ocean. As mentioned in the introduction, French actors on Isle de France became increasingly aware of the fact that nutmeg bears monosexual flowers. ${ }^{97}$ What we know today is that, while female plants bear the seeds, male plants with male flowers (which do not bear seeds) are indispensable for pollination and consequently reproduction.

Therefore, like other dioecious plants, nutmeg is more difficult to reproduce than monoecious plants. Only female trees yield nuts and therefore it was desirable to have more female trees. For all of these reasons, reproduction in great quantity was not straightforward. French cultivators struggled to put knowledge about sex in plants into strategic practice that would yield more plants in order to have more nuts. The recognition of nutmeg sex caused immense problems for the practical needs of reproduction on Isle de France.

In the following, examining the practical challenges of dioecious plant breeding on Isle de France, I will test the hypothesis that Maluku knowledge did not necessarily contribute to the application of such knowledge. Here only through the lens of knowledge application does the practical problem of dioecious plants become evident. How cultivators on Isle de France interpreted Maluku knowledge remains unclear. Here the question of sex was most crucial for practitioners: Céré's 1783 report on nutmeg trees illustrated this dilemma. He had male overpopulation, or rather a small female population, which was

95 Antoine Jacobsohn, 'Seed origins: new varieties of fruits and vegetables around Paris at the turn of the nineteenth century', in Sue Ann Prince (ed.), Of Elephants \& Roses: French Natural History, 1790-1830, Philadelphia: American Philosophical Society, APS Museum, 2013, pp. 65-77.

96 Jacobsohn, op. cit. (95), pp. 65-66; Thierry Hoquet, Buffon-Linné: Eternels rivaux de la biologie?, Paris: Dunod, 2007, p. 55; Taiz and Taiz, op. cit. (19).

97 On a discussion of a plant's sex from Leibniz to Linnaeus and classification in the Systema Naturae see Jean-Marc Drouin, L'herbier des philosophes, Paris: Seuil, 2008, pp. 110-123. 
insufficient for extensive reproduction and, consequently, for sustainable harvesting. ${ }^{98}$ Céré recognized the sex of these plants but an insurmountable obstacle remained: although he was aware of nutmeg's sexuality, he did not have the practical means to control it. He lacked the means to increase the population of fruit-bearing trees by planting female seeds.

Céré was plagued by fundamental questions. How did the tree the nut came from precondition the sex of the tree that would grow from it? Does each seed have the capacity to create a male or female offspring, or is there a way to know which nuts will grow to produce male or female plants? He proposed an impossible task: predicting the sex of an offspring from the seed available to the cultivator. ${ }^{99}$ Cére continued to labour on these problems from 1776 to 1783 , before concluding that he had reached the limits of his practical knowledge. At the same time he sought to conduct further experiments with different types of nutmeg (different shapes and forms). Céré argued that only when experimenting could observations 'enlighten us on the most prompt way of reproducing this precious gift of nature'. ${ }^{100}$

Céré accepted that, even if it was desirable, it remained impossible to know which seeds would grow into female trees. Indeed, it remains true that the sex of a seed cannot be determined by visual examination, and it is impossible to tell if a plant is female or male until the plant actually blooms. Yet focusing on cultivating nutmeg from seeds directly made Céré blind to experimentation with alternative methods. Here, the gardener slave Hilaire - whose origin remains unclear but who actually worked on the neighbouring French colonial island of La Réunion (present-day Bourbon) - initiated experiments with grafting clove using jamrosa as stock. Céré exclaimed that this was a method 'against the principles in France' of which he himself 'would never have thought'. ${ }^{101}$ Because the grafting was so promising, he conducted experiments with different stocks (orange, peach and pear trees) for nutmeg, which were initiated by the slave's practical suggestion after the master's techniques had failed. ${ }^{102}$ The example of grafting can highlight that similar kinds of knowledge practice were developed independently in different parts of the world. This argument goes hand in hand with the recognition of the sex of plants, as shown in the previous section.

98 Céré's report on the cultivation of spice plants, 4 November 1783, trancribed in Ly-Tio-Fane, The Odyssey of Pierre Poivre, op. cit. (31), pp. 100-112, 107, 111.

99 Céré's report, op. cit. (98).

100 Céré's report, op. cit. (98), p. 112.

101 Céré to Hubert, 10 October 1778, transcribed in Ly-Tio-Fane, The Triumph of Jean Nicolas Céré, op. cit. (31), pp. 43, 145-146.

102 Céré to Hubert, op. cit. (101). For studies concerning slaves' ethnobotanical knowledge see Susan Scott Parrish, 'Diasporic African sources of Enlightenment knowledge', in Delbourgo and Dew, op. cit. (45), pp. 281-310; Elizabeth Green Musselman, 'Plant knowledge at the Cape: a study in African and European collaboration', International Journal of African Historical Studies (2003) 36, pp. 367-392; Carney, op. cit. (23); Carney and Rosomoff, op. cit. (23). On slavery and science making see further Kathleen S. Murphy, 'Collecting slave traders: James Petiver, natural history, and the British slave trade', William and Mary Quarterly (2013) 70, pp. 637-670, James Delbourgo, Collecting the World: The Life and Curiosity of Hans Sloane, London: Penguin, 2017; Winterbottom, op. cit. (12), pp. 163-195. 
The garden became a space of heterogeneous knowledge traditions, which supported intellectual creolization. European knowledge was said to be superior but was quite the contrary: colonists relied on non-European knowledge traditions, practices and innovations. Here, Céré was so obsessed with the nuts that he was blind to alternative methods, such as grafting - a method that came to Isle de France together with Hilaire. One remote Indo-Pacific island became a laboratory where different knowledge traditions produced completely independently by distinct cultures of the Indo-Pacific world encountered and merged with each other.

\section{Conclusions}

This essay underlines the role of Indo-Pacific islands in two ways: the Maluku islands, so complex in terms of people and knowledge traditions, themselves also served as significant sources of plants and related knowledge. These two components arrived independently - at different points in time - in the creole island of Isle de France, which served as a site of experiments where knowledge was practised and adapted. Embodied knowledge did not arrive together with Maluku islanders but rather with people of European, South Asian and possibly African or Malagasy origin who possessed cultivational knowledge concerning other plants. In that sense, this case helps us to rethink the movement of plants, people and knowledge between islands at both ends of the Indo-Pacific.

When French actors tried to change the environmental landscape of Isle de France through the introduction of foreign crops from the Indo-Pacific world, natural and human forces interacted. Even when the live plants and seeds finally arrived on Isle de France, they did not promise immediate success, but quite the contrary. Because cultivational knowledge that arrived in the French colony was sometimes lost or inadequately explained, actors sometimes failed to create the perfect conditions for acclimatization. These obstacles were both human-caused when plants were handled in the wrong way, and occurred naturally due to environmental conditions, which could not be tamed.

While exploring a specific moment in the creolization of knowledge, I have argued more broadly against a French colonial machine and against overestimating the importance of taxonomic innovations in Europe for colonial science happening elsewhere. Scholars who have examined colonial botany in various contexts have focused on tracing local knowledge that entered - or in most cases did not enter - European scientific discourse. In so doing, they have neglected the local application and appropriation of knowledge that was being practised (or not) by historical actors. When knowledge does not travel, productive innovations become possible.

Cultural and environmental creolization took shape in distinctive Indo-Pacific knowledge practices. When knowledge and plants were accumulated on Isle de France, they responded to social, cultural and environmental components of the local environment. Cultivational techniques and plant processing had to adapt to the island's climate and other natural conditions. Here in particular, the case of nutmeg on Isle de France demonstrates the incomplete and uncertain knowledge about tropical agriculture and the appropriate handling of plant material there. 
Even when cultivation methods and the plants' needs were studied, there was a clear explanation of why the nutmeg did not reproduce well: the colonists of Isle de France lacked female nutmeg trees. The French did not have the means to increase the female tree population because they could not determine if a female or male specimen would grow from a seed. They lacked experience, and alternative solutions and methods were only developed through the initiative of the slave gardener Hilaire when his master had clearly failed. The particularity of Isle de France as an enclosed place that was nonetheless connected through the circulation of people, plants and knowledge made it a test site for the exploration of creolized knowledge that emerged alongside specific environmental practices. Bringing these elements meaningfully together contributes to a greater awareness of the appropriation of ideas and techniques from the Maluku islands to Isle de France, which have been neglected in works on colonial botany. 